\title{
NUTRITION ASSISTANCE INCREASES THE SIZE OF MIDDLE-UPPER ARM CIRCUMFERENCE OF PREGNANT WOMEN WITH CHRONIC ENERGY DEFICIENCY
}

\author{
Ellyani Abadi \& Linda Ayu Rizka Putri*
}

S1 Nutrition Study Program, STIKes Karya Kesehatan, Indonesia

Received: 24 October 2020 | Accepted: 30 November 2020

DOI: https://dx.doi.org/10.36685/phi.v6i4.354

\section{Correspondence:}

Linda Ayu Rizka Putri

STIKes Karya Kesehatan, Indonesia

Jl. Jend AH Nasution No 89 Anduonohu, Kendari, 93232, Indonesia

Email: lindarizkaputri@outlook.com

Copyright: (C) 2020 the author(s). This is an open-access article distributed under the terms of the Creative Commons Attribution Non-Commercial License, which permits unrestricted non-commercial use, distribution, and reproduction in any medium, provided the original work is properly cited.

\begin{abstract}
Background: Chronic Energy Deficiency (CED) in pregnant women is characterized by the size of middle-upper arm circumference (MUAC) $<23.5 \mathrm{~cm}$. In 2017, the prevalence of CED in Indonesia was $17.3 \%, 21.9 \%, 14.37 \%$, and $11.04 \%$, respectively, in Southeast Sulawesi, Kendari, and Puuwatu Health Center, which were still above the national target of 5\%. Thus, there is a need to overcome the CED problems by administering nutrition assistance to pregnant women.

Objective: This research aimed to understand the effect of nutrition assistance on the size of the middle-upper circumference of pregnant women with CED in the working area of Puuwatu Health Center, Kendari, Indonesia.

Methods: This study was a pre-experimental study with one group pretest-posttest design conducted from June to August 2020 in the working area of Puuwatu Health Center. As many as 35 pregnant women with CED living in the work area of Puuwatu Health Center during a period of January-August were enrolled in the study through a purposive sampling method. Later, the data were analyzed using a Wilcoxon sign rank test.

Results: There was an effect of nutrition assistance to the size of the middle-upper arm circumference of pregnant women with CED with a $\mathrm{p}$-value $=0.000$.

Conclusion: The nutrition assistance increases the size of the middle-upper arm circumference of pregnant women with CED in the working area of Puuwatu Health Center.
\end{abstract}

Keywords: chronic energy deficiency, middle-upper arm circumference, pregnant women

\section{BACKGROUND}

Chronic Energy Deficiency (CED) is a nutritional state which is characterized by a deficient energy intake for a period of several years (chronic), which results in some health problems (Prawita, indra Susanti, \& Sari, 2017). Pregnant women are susceptible to CED and can damage both mother and infant's health and the quality of the baby. Pregnant women with CED are at risk of longer delivery, postpartum bleeding, or even death. In addition, CED can also result in anemia, abnormal weight gain, susceptible to infection, premature delivery, low birth weight infant, damaged infant's growth and development such as stunting, brain development, and metabolic syndrome, which can lead to infectious disease in the future life (Effendy, Wirjatmadi, Adriani, \& Tosepu, 2015; Kementerian Kesehatan Republik Indonesia, 2015b; Wiirjatmadi, 2014). CED has become a global health problem, especially in developing countries. Globally, the prevalence of 
CED was about $35 \%-75 \%$. WHO also recorded that $40 \%$ of mother morbidity were attributable to CED (Rukiyah \& Yulianti, 2010) around a third of the Indian population experienced CED (Venkaiah, Brahmam, \& Vijayaraghavan, 2011). The prevalence of CED in the urban area was higher than in the rural area, respectively $56 \%$ and 36\% (Rao, Balakrishna, Arlappa, Laxmaiah, \& Brahmam, 2010).

As per data from the basic health survey in 2013, the national prevalence of CED in pregnant women aged $15-49$ years old was $24.2 \%$ and slightly decreased to $17.3 \%$ in 2018 (Kementerian Kesehatan Republik Indonesia, 2018). Southeast Sulawesi was among the provinces with a moderate prevalence of CED in 2017, 21.9\% (Dinas Kesehatan Sulawesi Tenggara, 2020), while in 2019, the prevalence of CED in Kendari and Puuwatu Health Center was respectively, $14.37 \%$ and $11.04 \%$ (Dinas Kesehatan Kota Kendari, 2020). These numbers reflect the high prevalence of CED that is still above the national target of 5\% as per the SDG's target 2015-2030 (Kementerian Kesehatan Republik Indonesia, 2015b).

CED can be identified through a middle-upper arm circumference (MUAC) measurement. A pregnant woman with MUAC $<23.5 \mathrm{~cm}$ is identified as CED (Kementerian Kesehatan Republik Indonesia, 2018). CED in pregnant women is caused by several direct and indirect factors. The direct factors of CED are nutrient deficiency, both macronutrients and micronutrients, and infectious diseases (Edowai, Rantetampang, Msen, \& Mallongi, 2018; UNICEF, 2015). While, the indirect factors of CED are knowledge, antenatal care, occupation, family's income, attitude, care pattern, mother's age, parity, environmental health, and health cares (Edowai et al., 2018; Effendy, 2009; Febriyeni, 2017; Fitrianingtyas, Pertiwi, \& Rachmania, 2018).

The government has delivered several efforts to address the CED problem, such as food supplementation to the pregnant women with CED and inter-program coordination through integrated cares for pregnant women (integrated antenatal cares), including early detection, and prompt nutritional treatments for CED, delivery preparation, and preparation for complication attributed to nutritional issues on pregnant women, disease prevention and its complications through the health counseling (Kementerian Kesehatan Republik Indonesia, 2015a). Likewise, several efforts to deal with CED have also been made at the Puuwatu Health Center including food supplementation, health education and counseling to the pregnant women regarding their nutritional requirements during pregnancy, as well as inter-professional collaboration and coordination, anthropometric monitoring and evaluation, especially the middle-upper arm circumference; nevertheless, there are still some pregnant women with CED found in Kendari especially at Puuwatu Health Center (Puskesmas Puuwatu, 2020).

Previous studies showed several efforts to alleviate the prevalence of CED on pregnant women including food supplementation. A study by Prawita et al. (2017) showed that all pregnant women with CED who received intervention gained weight and MUAC. Furthermore, a study done in Surabaya showed that food supplementation could improve the nutritional status of pregnant women regardless of other factors such as food pattern, food consumption, health status, and internal factors such as excessive workload and less knowledge on nutrition. Today, many factors affect the nutritional status of pregnant women with chronic energy deficiency (Nugrahini et al., 2014).

A study by Bookari, Yeatman, and Williamson (2017) also showed that pregnant women have high motivation and self-confidence in their ability to provide a healthy diet and meet dietary recommendations. Yet, in contrast, they showed less knowledge and adherence to the dietary recommendation given to them.

Hence, it is believed that nutrition assistance is required to increase mother's knowledge so that they can properly choose food to consume during pregnancy, and it will result in the size of their middle-upper arm circumference as well as another intervention that is often made, such as food supplementation without regular monitoring on food intake. Thus, there is a need for innovation to reduce the prevalence of CED on 
pregnant women in the form of nutrition assistance, which focused on routine and sustainable education using leaflet and determining dietary recommendation during pregnancy, food intake monitoring, and the middle-upper arm circumference measurement.

This present study aimed to understand the effect of nutrition assistance to increase the size of the middle-upper arm circumference of pregnant women with CED in the work area of Puuwatu Health Center, Kendari, Southeast Sulawesi, Indonesia.

\section{METHODS}

\section{Study Design and Participants}

This study was a pre-experimental study with one group pretest-posttest design. This present study was conducted from June to August 2020 in the work area of Puuwatu Health Center. There were 35 pregnant women enrolled in the study through a purposive sampling technique and were all in the third trimester of pregnancy.

\section{Instrument}

We used MUAC ribbon to measure the middleupper arm circumference and both fliers and leaflets as media to assist the nutritional intake of pregnant women.

\section{Intervention}

Interventions were made through the following steps:

1. Measuring the MUAC of pregnant women with CED before delivering nutrition assistance.

MUAC measurements are carried out in the middle, between the shoulder and the elbow of the left arm, where the arm must be free, meaning that the arm muscles are not tense, and also need to ensure the measuring instrument is not wrinkled (the surface is flat), then determine the location of the shoulder and the location of the middle elbow and determine the point the middle of the upper arm by extending the ribbon from the shoulder to the elbow, and determining the middle of the arm. Then loop the measuring tape right in the middle of the mother's upper arm and read the scale correctly. If the measurement is $<23.5 \mathrm{~cm}$, then the mother is classified as having CED.

2. Delivering nutrition assistance to pregnant women.

The first step in nutrition assistance was determining the nutrient requirements of pregnant women, followed by administering nutritional counseling using leaflets and fliers. The counseling was made at the integrated health service post, maternal and child health poly, and at mother's home. The counseling was delivered four times, wherein the $1^{\text {st }}$ and $4^{\text {th }}$ counseling were delivered offline. Meanwhile, the $2^{\text {nd }}$ and $3^{\text {rd }}$ counseling were given online. The online counseling was made as part of covid-19 transmission control.

3. Measuring the MUAC of pregnant women with CED after delivering nutrition assistance.

The MUAC measurements were made after delivering 3-month nutrition assistance to pregnant women.

\section{Data Analysis}

The normality test was made through a ShapiroWilk test, and later the Wilcoxon sign rank test was used to test the hypothesis. The normality showed a p-value of 0.000 , and therefore the data were not normally distributed.

\section{Ethical Consideration}

This study was approved by the Research Ethics Committee of IAKMI Pengda Sultra with an approval number: 132/KEPKIAKMI/VII/2020. Informed consent was signed by each participant in this study.

\section{RESULTS}

Table 1 shows that majorities of the respondents were in the age category of $20-35$ years $(65.7 \%)$ with a mean age of 26 years old, the youngest was 15 years old, and the oldest was 43 years old. Meanwhile, most of the respondents were in the 32-35 weeks of pregnancy, with a mean of 33 weeks, the lowest was 28 weeks, and the highest was 37 weeks. $62.9 \%$ of respondents were senior 
high graduates, and $88.6 \%$ were household wives.

Table 1 Respondents' Characteristics

\begin{tabular}{lcc}
\hline Variable & n (35) & \% \\
\hline Mother's age (year) & \multicolumn{2}{c}{} \\
$<20$ & 7 & 20.0 \\
$20-45$ & 23 & 65.7 \\
$>35$ & 5 & 14.3 \\
Mean (Min-Max) & $26(15-43)$ \\
Week of pregnancy (week) & \multicolumn{2}{c}{} \\
$28-31$ & 5 & 14.3 \\
$32-35$ & 19 & 54.3 \\
$36-40$ & 11 & 31.4 \\
Mean (Min-Max) & \multicolumn{2}{c}{$33(28-37)$} \\
Education level & \multicolumn{2}{c}{} \\
Elementary school & 1 & 2.9 \\
Junior high & 8 & 22.9 \\
Senior high & 22 & 62.9 \\
Undergraduate & 4 & 11.4 \\
Occupation & \multicolumn{2}{c}{} \\
Civil servants & 1 & 2.9 \\
Entrepreneur & 3 & 8.6 \\
Household wives & 31 & 88.6 \\
\hline
\end{tabular}

Table 2 Nutritional status of pregnant women before and after assistance

\begin{tabular}{lcrrrrr}
\hline \multirow{2}{*}{ MUAC } & \multicolumn{2}{c}{ CED } & \multicolumn{2}{c}{ Not CED } & \multicolumn{2}{c}{ Total } \\
& n & \% & n & \% & n & \% \\
\hline Pretest & 35 & 100 & 0 & 0 & 35 & 100 \\
Posttest & 17 & 49 & 18 & 51 & 35 & 100 \\
\hline
\end{tabular}

Table 2 shows that before nutrition assistance, all pregnant women experienced CED (100\%), while after intervention delivered, some mothers experienced CED for $49 \%$ and the other $51 \%$ were no longer experiencing CED.

Table 3 The effect of nutrition assistance on the size of MUAC

\begin{tabular}{lcccc}
\hline MUAC & $\begin{array}{c}\text { Mean } \\
(\mathbf{c m})\end{array}$ & SD & $\begin{array}{c}\text { Min-Max } \\
(\mathbf{c m})\end{array}$ & p-value \\
\hline Pretest & 22.14 & 1.16 & $19-23$ & $0.000^{*}$ \\
Posttest & 23.28 & 0.89 & $20-25$ & \\
\hline
\end{tabular}

Table 3 shows the average size of MUAC in pregnant women with CED before nutrition assistance was $22.14 \mathrm{~cm}$, with a standard deviation of 1.16. meanwhile, there was an increase in MUAC after assistance to $23.28 \mathrm{~cm}$ with a standard deviation of 0.89 . Meanwhile, the result of the Wilcoxon sign rank test showed a pvalue of 0.000 , indicating an effect of nutrition assistance on the size of the middle-upper arm circumference of pregnant women at Puuwatu Health Center, Kendari, Indonesia.

\section{DISCUSSION}

In our study, nutrition assistance can increase the size of the middle-upper arm circumference (MUAC) of pregnant women with CED with a mean increase of $1.14 \mathrm{~cm}$. The nutrition assistance was delivered by determining the nutritional status, providing daily food recommendations, food intake monitoring, nutritional counseling, and health education about the role of maternal nutrition during pregnancy using a leaflet about food recommendation and restriction during pregnancy. Respondents were also able to consult their nutritional problems as well as food intake recommendation during pregnancy.

The increase of MUAC on pregnant women with CED is also supported by the mother's age, week of pregnancy, education, and mother's occupation, which affects their knowledge and can change one's behavior in selecting food to consume and later affects the size of MUAC. In our study, the majority of the respondents aged 20-35 years old. At this age, mothers are good enough to receive information and assistance. A study by Pamarta and Andriani (2018) showed that at the age of 20-35 years, women could fulfill their food intake.

In our study, the respondents were all in the $3^{\text {rd }}$ trimester of pregnancy. In this stage, pregnant women already had a better appetite after experiencing emesis or vomitus during the $1^{\text {st }}$ and $2^{\text {nd }}$ trimester of pregnancy. This condition is able to develop the mother's concentration in accepting health education. Furthermore, since majorities of respondents were senior high school graduates, they could better understand nutrition recommendations and education. Besides, because most of the respondents were household wives, they could thoroughly join nutrition assistance.

Therefore, the mother's age, week of pregnancy, information, education, and occupation are factors that can affect one's knowledge-the 
more information received by the pregnant women, the better the knowledge, attitude, and behavior. Hence, nutrition assistance can increase mother's knowledge, affect food intake, and increase the size of MUAC in pregnant women with CED. A study by Kasrida Dahlan (2019) showed an effect of nutrition counseling on the macronutrient intake of pregnant women with CED in Palopo in 2019.

The nutrition assistance was delivered four times; the first assistance during pre-test data collection, the second and third assistances were given using the WhatsApp application, and the last assistance was provided directly to the pregnant women, followed by MUAC measurement. In fact, nutrition assistance can directly affect pregnant women's behavior to consume nutritious food and thus positively increase the size of the middle-upper arm circumference on pregnant women with CED.

This present study is in line with a study by Prawita et al. (2017) that showed that all pregnant women with CED supported by food supplementation and health counseling had an increase in their body weight and MUAC. Likewise, a study by Silitonga (2018) also found that there is a significant association between nutritional counseling and body weight gain of pregnant women with CED.

Nutritional counseling given to pregnant women aims to improve their nutritional status by providing food according to the needs of pregnant women to achieve optimal nutritional status. This condition is also in line with service standards that pregnant women need to be given nutritional services to provide education so that mothers can improve their nutritional status during pregnancy (Wiirjatmadi, 2014). The nutritional counseling can increase the knowledge and motivation of pregnant women to adopt a healthy diet during pregnancy to increase normal body weight, which is a manifestation of a healthy diet applied by pregnant women (Hapzah \& Siradjuddin, 2013). A study by Mahmudah (2020) found that there is an effect of health education on the increase of nutritional knowledge of pregnant women with CED in Mojokerto Regency.
During the provision of nutrition assistance, pregnant women understand their nutritional requirements. It is hoped that pregnant women with CED can apply the information provided during assistance to change the nutritional status from CED to a normal level.

\section{CONCLUSION}

The nutrition assistance can increase the middleupper arm circumference size on pregnant women with CED at Puuwatu Health Center, Kendari, Southeast Sulawesi. The nutrition assistance program is hoped to be of the programs to alleviate the prevalence of CED. Further studies are required to analyze factors associated with the size of the middle-upper arm circumference of pregnant women with CED.

Declaration of Conflicting Interest

We declare that there is no conflicting interest in this study.

Acknowledgment

We deeply acknowledge all the study participants, all the staff and health professionals of the Puuwatu health center, supervisors, and all data collectors for their cooperation and commitment throughout this study.

References

Bookari, K., Yeatman, H., \& Williamson, M. (2017). Falling short of dietary guidelines-What do Australian pregnant women really know? A cross sectional study. Women and Birth, 30(1), 9-17.

Dinas Kesehatan Sulawesi Tenggara. (2020). Profil kesehatan Sulawesi Tenggara. Sulawesi Tenggara: Dinas Kesehatan Sulawesi Tenggara.

Edowai, N., Rantetampang, A., Msen, Y., \& Mallongi, A. (2018). Factors influencing with malnutrition pregnant at Tigi district Deiyai regency. International Journal of Science \& Healthcare Research, 3(4), 245-256.

Effendy, D. S. (2009). Pengaruh pemberian makanan tambahan lokal dan susu 123 terhadap peningkatan status gizi balita gizi kurang usia 12-24 bulan. Surabaya: Universitas Airlangga,

Effendy, D. S., Wirjatmadi, B., Adriani, M., \& Tosepu, R. (2015). The influence of supplementary feeding by local food and 123 milk toward increasing the nutritional status of 12-24 months children with undernutrition status in southeast Sulawesi province, Indonesia. International Journal of Research in Medical Sciences, 3(10), 2704.

Febriyeni. (2017). Factors associated with chronic energy deficiency in pregnant women. Human Care Journal, 2(3).

Fitrianingtyas, I., Pertiwi, F. D., \& Rachmania, W. (2018). Faktor-Faktor yang berhubungan dengan kejadian kurang energi kronis (KEK) pada ibu hamil di 
Puskesmas Warung Jambu Kota Bogor. HEARTY: Jurnal Kesehatan Masyarakat, 6(2).

Hapzah, H. V., \& Siradjuddin, S. (2013). Pengaruh konseling gizi mikro dua kali seminggu terhadap peningkatan kadar hemoglobin dan asupan makanan ibu hamil. Media Gizi Masyarakat Indonesia, 2(2), 64.

Kasrida, D, A. (2019). Pengaruh penerapan konseling sadar gizi terhadap jumlah makronutrien pada ibu hamil mengalami KEK di Kota Palopo. Palopo: Universitas Muhammadiyah Palopo.

Kementerian Kesehatan Republik Indonesia. (2015a). Profil kesehatan Republik Indonesia. Jakarta: Kementerian Kesehatan Republik Indonesia.

Kementerian Kesehatan Republik Indonesia. (2015b). Rencana Strategis Kementerian Kesehatan 2015-2019. Jakarta: Kementerian Kesehatan Republik Indonesia.

Kementerian Kesehatan Republik Indonesia. (2018). Hasil utama riset kesehatan dasar tahun 2018. Jakarta: Kementrian Kesehatan Republik Indonesia.

Mahmudah, R. L. (2020). Efektivitas promosi peningkatan gizi pada ibu hamil kekurangan energi kronik studi di wilayah Kabupaten Mojokerto. Medica Majapahit (Jurnal Ilmiah Kesehatan Sekolah Tinggi Ilmu Kesehatan Majapahit), 12(1), 25-35.

Nugrahini, E., Effendi, J., Herawati, D., Idjradinata, P., Sutedja, E., \& Mose, J. (2014). Asupan energi dan protein setelah program pemberian makanan tambahan pemulihan ibu hamil kurang energi kronik di Puskesmas Kota Surabaya. Jurnal Pendidikan dan Pelayanan Kebidanan Indonesia, 1(1), 41-47.

Pamarta, D., \& Andriani, K. (2018). The influence of mother's predisposing factors (age, education, occupation, knowledge, attitude) on accuracy of complementary feeding with breast milk (MPASI) in Kenep Village, Sukoharjo District, Sukoharjo Regency. Surakarta: University of Muhammadiyah Surakarta.

Prawita, A., indra Susanti, A., \& Sari, P. (2017). Survei intervensi ibu hamil Kurang Energi Kronik (KEK) di
Kecamatan Jatinangor Tahun 2015. Jurnal Sistem Kesehatan, 2(4).

Puskesmas Puuwatu. (2020). Profil kesehatan Puskesmas Puuwatu. Puuwatu: Puskesmas Puuwatu.

Rao, K. M., Balakrishna, N., Arlappa, N., Laxmaiah, A., \& Brahmam, G. (2010). Diet and nutritional status of women in India. Journal of Human Ecology, 29(3), 165-170.

Rukiyah, A. Y., \& Yulianti, L. (2010). Asuhan kebidanan IV (patologi kebidanan). Jakarta: Trans Info Media.

Silitonga, K. (2018). Hubungan kehadiran konseling gizi dan konsumsi PMT (Pemberian Makanan Tambahan) program dengan pertambahan $B B$ ibu hamil KEK (Kekurangan Energi Kronik) di Puskesmas Ngaliyan Kota Semarang tahun 2017. Semarang: Universitas Muhammadiyah Semarang,

UNICEF. (2015). UNICEF's approach to scaling up nutrition for mothers and their children. UNICEF. Retrieved from https://www.unicef.org/nutrition/files/Unicef Nutritio n_Strategy.pdf

Venkaiah, K., Brahmam, G., \& Vijayaraghavan, K. (2011). Application of factor analysis to identify dietary patterns and use of factor scores to study their relationship with nutritional status of adult rural populations. Journal of Health, Population, and Nutrition, 29(4), 327.

Wiirjatmadi, B. (2014). Guidelines for overcoming Chronic Energy Deficiency (CED) in pregnant women. UNICEF.

Cite this article as: Abadi, E., \& Putri, L. A. R. (2020). Nutrition assistance increases the size of middle-upper arm circumference of pregnant women with chronic energy deficiency. Public Health of Indonesia, 6(4), 157-162. https://dx.doi.org/10.36685/phi.v6i4.354 